\title{
An experimental study of hydroxylbastnasite solubility in aqueous solutions at $25^{\circ} \mathrm{C}$
}

\author{
Martin Voigt ${ }^{\mathrm{a}, *}$, Juan Diego Rodriguez-Blanco ${ }^{\mathrm{b}}$, Beatriz Vallina ${ }^{\mathrm{c}}$, Liane G. Benning ${ }^{\mathrm{c}, \mathrm{d}}$, Eric H. Oelkers ${ }^{\mathrm{a}, \mathrm{e}}$ \\ a GET/CNRS, 14 avenue Édouard Belin, 31400 Toulouse, France \\ b Nano-Science Center, University of Copenhagen, Universitetsparken 5, 2100 København, Denmark \\ c School of Earth and Environment, University of Leeds, Leeds LS2 9JT, United Kingdom \\ d GFZ - Helmholz Centre Potsdam, Telegrafenberg, 14473 Potsdam, Germany \\ e Earth Sciences, UCL, Gower Street, London, United Kingdom
}

\section{A R T I C L E I N F O}

\section{Article history:}

Received 21 January 2016

Received in revised form 11 March 2016

Accepted 12 March 2016

Available online 16 March 2016

\section{Keywords:}

Rare earth elements

Bastnasite

Kozoite

Solubility

Carbonate

Thermodynamics

\begin{abstract}
A B S T R A C T
The mobility of rare earth elements (REEs) in natural aqueous solutions is of increasing interest due to their application in numerous high-tech and renewable energy technologies (e.g., wind turbines and electric vehicles), as well as their role as tracers in the Earth Sciences. Basic thermodynamic data for water-rock interactions are, however, sparse and partially inconsistent, even for carbonate minerals of the bastnasite group $\left(\operatorname{REE}\left(\mathrm{CO}_{3}\right)(\mathrm{OH}, \mathrm{F})\right)$, which currently represent the most exploited REE ore. Towards the improved quantification of the REE in natural and industrial systems, pure hexagonal hydroxylbastnasite and orthorhombic kozoite $\left(\operatorname{REE}\left(\mathrm{CO}_{3}\right)(\mathrm{OH})\right)$ were synthesized at hydrothermal conditions and subsequently used as starting material for aqueous dissolution and precipitation experiments. All closed system experiments were performed in air equilibrated aqueous fluids. Reaction progress was followed by measuring $\mathrm{pH}$ and REE concentrations at regular intervals. Experiments at $25{ }^{\circ} \mathrm{C}$ in the presence of selected concentrations of $\mathrm{HCl}$ and $\mathrm{NaOH}$ were run for up to 33 days until steady-state $\mathrm{pH}$ and REE concentrations were attained. Results indicate that the solubility products $\left(K_{S P}\right)$ of the reaction $\operatorname{REE}\left(\mathrm{CO}_{3}\right)(\mathrm{OH})=\mathrm{REE}^{3+}+\mathrm{CO}_{3}^{2-}+\mathrm{OH}^{-}$are $\log \left(K_{S P}\right)=-23.8 \pm 0.1,-24.1 \pm 0.3$, and $-22.3 \pm 0.2$ for Nd-, La-hydroxylbastnasite, and Nd-kozoite, respectively at $25^{\circ} \mathrm{C}$.
\end{abstract}

(c) 2016 Elsevier B.V. All rights reserved.

\section{Introduction}

The rare earth elements (REEs) are of particular interest due to their various applications in geosciences and high-technology components (e.g., Binnemans et al., 2013; Jordens et al., 2013; McLellan et al., 2013; Preinfalk and Morteani, 1989). Their use as tracers of geological processes arises from their relatively similar chemical behaviour but gradually decreasing ionic size from lanthanum to lutetium, leading to distinct REE concentration patterns of the REE in the different phases (e.g., Elderfield et al., 1990; Lipin and McKay, 1989; Schnetzler and Philpotts, 1970). If these signatures are preserved, they can help identify the provenance and nature of processes that lead to their formation (e.g., Elderfield and Greaves, 1982; Mckenzie and Onions, 1991; Taylor and Mclennan, 1995). Furthermore, the study of REE bearing minerals can help identify metamorphic or metasomatic processes in a variety of natural settings (e.g., Gysi et al., 2015; Harlov et al., 2010). Apart from scientific applications, there is an increasing demand for REEs as they can be exploited to create high strength permanent magnets, phosphors for electronic displays and various components in renewable energy technologies (Jordens et al., 2013). Along with monazite, xenotime,

\footnotetext{
* Corresponding author.

E-mail address: martin.voigt@get.obs-mip.fr (M. Voigt).
}

and ion-adsorbed clays, the mineral bastnasite $\left(\mathrm{REE}(\mathrm{F}, \mathrm{OH}) \mathrm{CO}_{3}\right)$ is one of the main ores exploited for the rare earths, with the majority currently mined in China (Jordens et al., 2013; Wang et al., 2015; Wübbeke, 2013). Major deposits of this carbonate mineral are found in association with carbonatites, peralkaline granites and syenites, veins/breccia, or, as in the case of the largest REE mine Bayan Obo (China), in sedimentary formations that underwent periods of magmatic, metamorphic and metasomatic overprint (Migdisov and Williams-Jones, 2014; Smith et al., 2015; Williams-Jones and Wood, 1992). Naturally occurring bastnasite is usually close in composition to its fluoro endmember $\left(\mathrm{REEFCO}_{3}\right)$ with lower low amounts of $\mathrm{OH}^{-}$present, causing interest in fluoride-bearing aqueous solutions (Migdisov et al., 2009). Apart from this economic interest, the hydroxylbastnasite endmember $\left.(\mathrm{REEOHCO})_{3}\right)$, as well as other rare earth element hydroxides and carbonates, are of interest due to their potential for nuclear waste storage (Rorif et al., 2005); the rare earths can be used as an analogue for long-lived actinides due to their similar electron configuration, motivating experiments aiming at predicting their behaviour (e.g., Rorif et al., 2005; Runde et al., 1992; Stipp et al., 2006). The REEs can also form as fission products. As such, REE hydroxides or carbonates could form from the interaction of nuclear waste with natural waters, and thereby serve as potential host minerals for long-lived actinides (Rorif et al., 2005). 
Despite its role in a plethora of processes, relatively few studies have assessed the stability of hydroxylbastnasite in presence of aqueous solutions. Although several studies have measured the solubility of the orthorhombic polymorph kozoite $\left(\mathrm{REEOHCO}_{3}\right.$; Carroll, 1993; Meinrath and Kim, 1991; Meinrath and Takeishi, 1993; Runde et al., 1992) no study to date has directly measured hydroxylbastnasite solubility in aqueous solutions, and it is not clear which polymorph is thermodynamically stable at low temperature conditions. The thermodynamic properties of hydroxylbastnasite were inferred, however, from thermochemical data by Rorif et al. (2005). Towards the improved description of the behaviour of the rare earth elements in natural systems we have carried out a series of experiments at $25^{\circ} \mathrm{C}$ to assess the solubility of the two $\mathrm{REEOHCO}_{3}$ polymorphs hydroxylbastnasite and kozoite via dissolution and precipitation experiments in aqueous solutions and in presence of $\mathrm{CO}_{2}$. This experimental data will enable comparison of the stability of both $\mathrm{REEOHCO}_{3}$ polymorphs. The purpose of this manuscript is to report the results of these experiments and use these to assess the stability of these minerals in low-temperature natural systems.

\section{Methods}

\subsection{Synthesis of starting materials}

Pure Nd- and La-hydroxylbastnasite, and Nd-kozoite crystals were synthesized hydrothermally as described by Vallina et al. (2014) to obtain minerals with pure end-member compositions. Briefly, aqueous solutions with a concentration of $50 \mathrm{mM}$ of the desired REE-chloride were mixed with $50 \mathrm{mM} \mathrm{Na}_{2} \mathrm{CO}_{3}$ solutions at ambient temperature, provoking the immediate precipitation of an amorphous rare earth element carbonate phase. This material was subsequently heated to $165^{\circ} \mathrm{C}$ in titanium reactors placed in rocking furnaces or in Teflon-lined reactors that were manually shaken at regular intervals. This procedure was performed at saturated water-vapour pressure using slow heating rates where the final temperature was reached in approximately $100 \mathrm{~min}$. Synthesis was carried out at $165^{\circ} \mathrm{C}$ to promote the formation of micrometric-sized crystals, because at higher temperatures the formation of spherulites (consisting of nanometric sized crystals) is promoted (Vallina et al., 2015). At $165{ }^{\circ} \mathrm{C}$ hydroxylbastnasite forms from kozoite by dissolution-recrystallisation, a relatively slow growth process (hours-days) compared to spherulitic growth (secondsminutes). Synthesis products were quenched after 1 to 4 weeks, filtered through $0.22 \mu \mathrm{m}$ membrane filters, washed with ultrapure water and isopropanol and dried at ambient temperature. Synthesis of both hydroxylbastnasite and kozoite, was possible by seeding the solutions with previously produced crystals of the selected mineral. The synthesis of hydroxylbastnasite and kozoite end-members with heavier REEs was not possible using this method, presumably due to their distinct in ionic radii.
The crystalline products were analysed by X-ray diffraction (XRD) to verify the crystal structure and by scanning electron microscopy (SEM) to examine the size and shape of the individual crystals. Crystal size was $>5 \mu \mathrm{m}$ (Fig. 1), so that the influence of particle size on solubility is expected to be negligible. For all syntheses, the powder was found to be entirely composed of either hydroxylbastnasite or kozoite within the detection limit of approximately $0.1 \%$ by comparison to the structural data of Ni et al. (1993) and Tahara et al. (2007), respectively (Fig. 2).

\subsection{Experimental design}

All solubility experiments were performed at $25 \pm 1{ }^{\circ} \mathrm{C}$ using reactors immersed in a thermostatically controlled water bath (Fig. 3 ). The temperature was restricted to $25^{\circ} \mathrm{C}$ in this study because of the lack of precise stability constants for aqueous rare earth element complexes in aqueous solutions at higher temperatures: The interpretation of a preliminary dissolution experiment, carried out at $110{ }^{\circ} \mathrm{C}$ in a closed titanium reactor in equilibrium with a fixed $\mathrm{CO}_{2}$ pressure of $500 \mathrm{kPa}$ indicated that uncertainties associated with available REE complex stability constants are larger than the difference in the solubility product between $110{ }^{\circ} \mathrm{C}$ and $25{ }^{\circ} \mathrm{C}$. The experimental aqueous solutions were kept in $1 \mathrm{~L}$ polyethylene (PE) reactors and mixed with fish-clip stir bars (Bürkle $\mathrm{GmbH}$ ) to avoid the grinding of the solids. Reactive fluid equilibrium with a constant $\mathrm{CO}_{2}$ partial pressure $\left(p \mathrm{CO}_{2}\right)$ of $\log \left(p \mathrm{CO}_{2}\right)=-3.30 \pm 0.04$ was maintained by bubbling air into the aqueous solution using a peristaltic pump. To minimize fluid loss during the experiment, the air was pre-saturated with water vapour by bubbling it through ultrapure water (resistivity of $18.2 \mathrm{M} \Omega$ ) twice before bubbling it into the reactor, and the gas outlet of the reactor was equipped with an air-cooled condenser (Fig. 3). All parts of the reactors and the sampling vials were cleaned prior to each experiment by soaking them in a solution comprised of $1 \mathrm{M} \mathrm{HCl}$ and ultrapure water for one day and subsequent repeated rinsing with ultrapure water. Experimental fluids were prepared with ultrapure water, bidistilled $\mathrm{HCl}$ or reagent grade $\mathrm{NaOH}$ to attain the $\mathrm{pH}$ of interest, and reagent grade $\mathrm{NaCl}$ was added to adjust the ionic strength (I). Sampling was carried out with a polypropylene syringe and sampled fluids were immediately filtered through a $0.45 \mu \mathrm{m}$ cellulose acetate membrane.

For dissolution experiments, the reactive fluids were sampled after approximately 1 week before the addition of the mineral powder to monitor experimental blank concentrations. Next, $0.15 \mathrm{~g}$ or $0.05 \mathrm{~g}$ of the desired mineral powder was added to the reactor for experiments at $\mathrm{pH}$ below and above 7, respectively. Sampling of approximately $5 \mathrm{~mL}$ of the fluid phase was carried out at regular intervals to monitor the temporal evolution of $\mathrm{pH}$ and REE concentrations. Experiments were terminated after steady state was achieved, indicated by both parameters showing no significant change over a time period of at least 4 days. For some experiments, $\mathrm{HCl}$ was added subsequently to the fluid phase to decrease $\mathrm{pH}$ and to achieve a new steady state at another

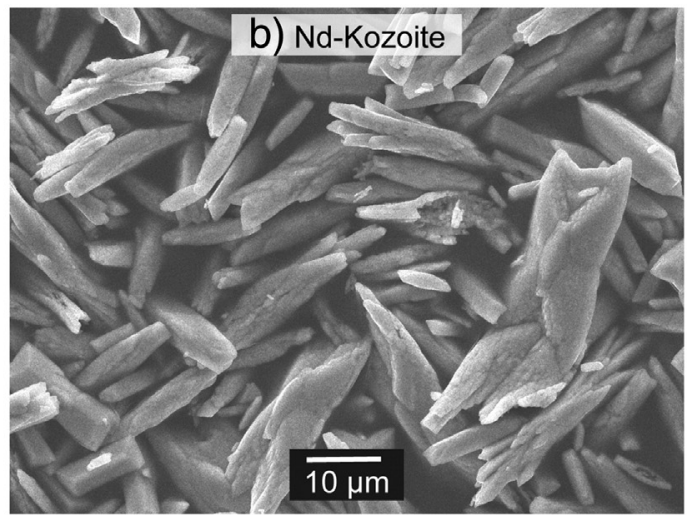



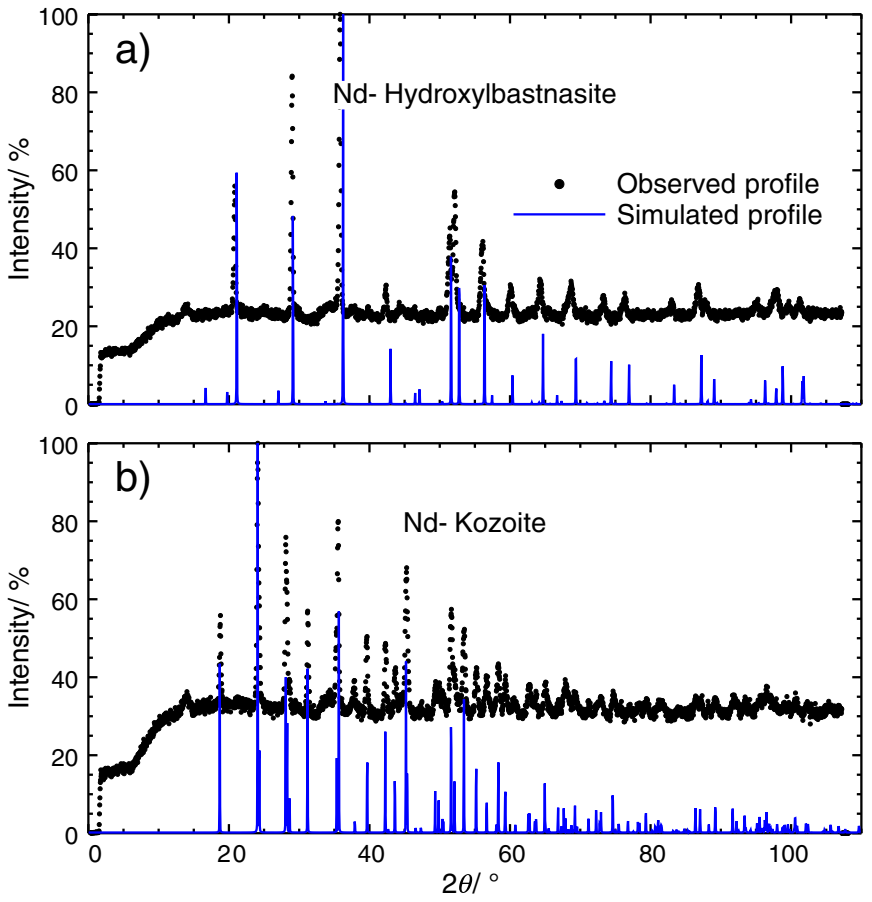

Fig. 2. XRD spectra (relative intensities vs. $2 \Theta$, Co-K $\alpha$ ) of hydrothermally synthesized (a) Nd-hydroxylbastnasite and (b) Nd-kozoite (symbols) compared to synthetic XRD patterns calculated from the structural data of Ni et al. (1993) and Tahara et al. (2007) (blue lines). (For interpretation of the references to color in this figure legend, the reader is referred to the web version of this article.)

$\mathrm{pH}$. Due to sampling, the volumes of the reactive fluids decreased from an initial $385 \pm 30 \mathrm{~mL}$, but always remained more than $75 \%$ of this initial value. After each experiment, the remaining powder was filtered, rinsed with ultrapure water multiple times, dried at ambient temperature, and examined by XRD and SEM to verify that no phase change occurred during the experiment.

To verify thermodynamic equilibrium, precipitation experiments were carried out as well. For these experiments, the reactive fluid $\mathrm{pH}$ of a dissolution experiment that already attained steady state was increased by adding a small volume of $\mathrm{NaOH}$ to the fluid phase. This induced the precipitation of a REE carbonate phase due to its decreasing solubility with increasing $\mathrm{pH}$. Fluid sampling was performed to monitor attainment of a new steady state by applying the same criteria as in dissolution experiments. At the end of these experiments, the solids were filtered and dried, and analysed by XRD.

\subsection{Analytical methods}

The $\mathrm{pH}$ of all sampled fluids was measured in situ using a VWR double junction epoxy electrode. For each $\mathrm{pH}$ measurement, the solution was stirred until a stable potential was attained. Subsequently, stirring was stopped and the potential was recorded when it restabilized (generally this required less than $10 \mathrm{~s}$ ). Stirring was stopped to avoid the build-up of stirring potentials in the low ionic-strength solutions; this method was found to yield reproducible results. The $\mathrm{pH}$ electrode was calibrated with three NIST traceable pH buffer solutions ( $\mathrm{pH} 4.0,6.9$, 9.2, Fluka) before each use at the experimental temperature. Different ionic strengths of the $\mathrm{pH}$ buffers and experimental solutions can potentially lead to a measurement bias due to the different liquid junction potentials. However, no correction for this bias was applied, because its magnitude is likely smaller than the uncertainty of the $\mathrm{pH}$ measurements (Kadis and Leito, 2010).

Aqueous rare earth element concentrations were determined by Inductively Coupled Plasma-Mass Spectrometry (ICP-MS) using a Thermo Scientific Element XR or Agilent 7500ce. Prior to analysis, samples were acidified to $\sim 0.37 \mathrm{~mol} / \mathrm{kg} \mathrm{HNO}_{3}$ using bi-distilled acid, and known concentrations of In and Re were added as internal standards. Standards were prepared using NIST traceable PlasmaCal single element standards (SCP Science). Detection limits, determined by analysis of blanks that were subjected to the same experimental and analytical procedures as actual samples, are approximately $2 \times 10^{-11} \mathrm{~mol} / \mathrm{kg}$. Gaseous $\mathrm{CO}_{2}$ concentrations were determined with a non-dispersive infra-red (NDIR) $\mathrm{CO}_{2}$ gas analyser (model LI-820, LICOR Inc.). Solid experimental products were analysed by X-ray powder diffraction using a Co source and by SEM using a Quanta 3D FEG or Jeol JSM 6360LV equipped with an energy-dispersive X-ray spectrometer (EDS).

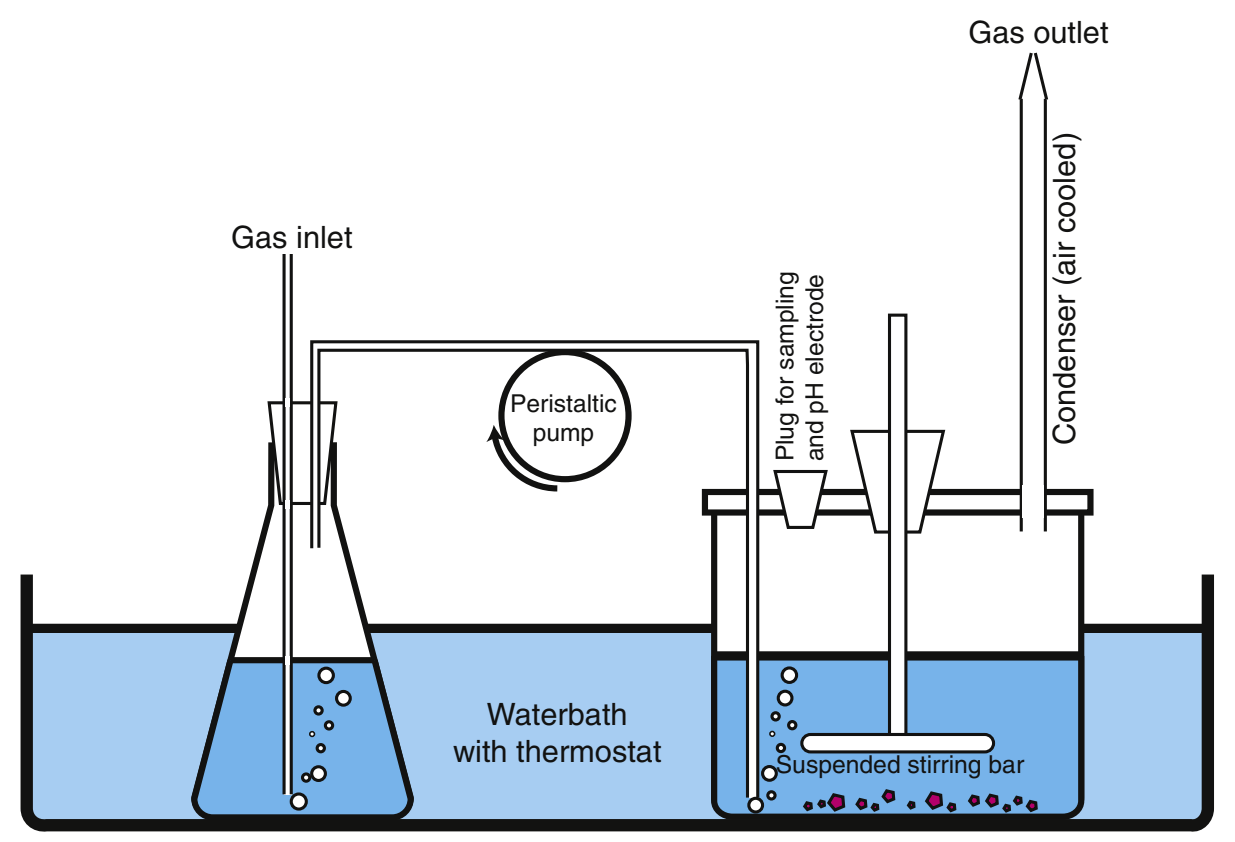

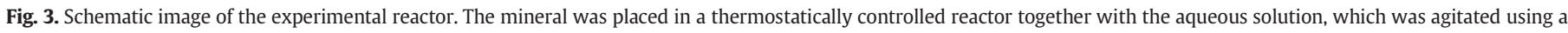

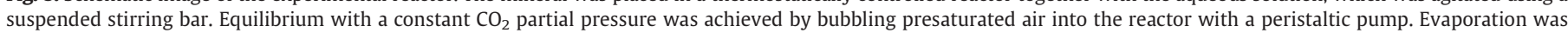
minimized by an air-cooled condenser. 


\subsection{Thermodynamic modelling}

Thermodynamic calculations of systems at equilibrium were performed using the PHREEQC software package (Parkhurst and Appelo, 2013) together with its Lawrence Livermore National Laboratory (LLNL) database (Johnson et al., 2000). Standard state for solid phases and $\mathrm{H}_{2} \mathrm{O}$ is the pure phase, while a hypothetical $1 \mathrm{~m}$ aqueous solution referenced to infinite dilution is chosen for unit activity of aqueous species, both at the temperature and pressure of interest. The Livermore National Laboratory aqueous model (Daveler and Wolery, 1992), which uses the extended Debye-Hückel equation of Helgeson (1969) was used to calculate activity coefficients. Due to the low ionic strengths of all experimental fluids considered in this study, the choice of activity model does not significantly affect retrieved reaction quotients. We chose the Helgeson (1969) activity model to insure all calculations were consistent with the LLNL database. Since the only aqueous REE complexes present in significant amounts in the experimental solutions are $\mathrm{REECO}_{3}{ }^{+}$and $\operatorname{REE}\left(\mathrm{CO}_{3}\right)_{2}{ }^{-}$, the total (measured) REE concentration

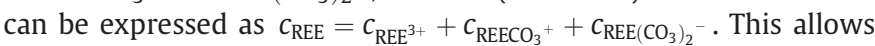
the calculation of $c_{\mathrm{REE}^{3+}}$, the activity $a_{\mathrm{REE}^{3+}}$ and thus the solubility products of the minerals of interest using the stability constants of the complexes and the activity model. The stability constants for the $\mathrm{REECO}_{3}{ }^{+}$ and $\operatorname{REE}\left(\mathrm{CO}_{3}\right)_{2}{ }^{-}$aqueous complexes were taken from Ohta and Kawabe (2000) and listed in Table 1 with other equilibrium constants used in this study. To assess the uncertainty of PHREEQC calculations caused by uncertainty in input parameters, Monte Carlo type simulations were run using the IPhreeqc modules (Charlton and Parkhurst, 2011) in combination with Wolfram Mathematica.

\section{Results}

\subsection{Evolution of aqueous solution compositions and solids}

Experimental parameters as well as reactive aqueous solution compositions at steady state are listed in Table 2 . During the dissolution experiments, stable $\mathrm{pH}$ and aqueous REE concentrations were attained after 6 to 33 days (Fig. 4). A decrease of dissolution rates with increasing $\mathrm{pH}$ was observed, however the lack of information on the specific surface areas of the reacting solids, as well as large sampling intervals in some experiments prevent the quantification of mineral dissolution rates from these data. The appearance of the minerals used in dissolution experiments remained unchanged under the SEM, and XRD patterns were identical before and after the experiments.

In experiments where the precipitation of hydroxylbastnasite or kozoite was induced, the addition of $\mathrm{NaOH}$ caused a rapid decrease of

Table 1

Values of equilibrium constants of reactions used in the thermodynamic calculations, as well as the solubility products obtained in this study (cf. Section 3.3 'Solubility product calculations'). HB: Hydroxylbastnasite.

\begin{tabular}{|c|c|c|}
\hline Reaction & $\log K$ & Source \\
\hline $\mathrm{La}^{3+}+\mathrm{CO}_{3}^{2-}=\mathrm{LaCO}_{3}^{+}$ & 12.52 & $\begin{array}{l}\text { Ohta and Kawabe } \\
(2000)\end{array}$ \\
\hline $\mathrm{La}^{3+}+2 \mathrm{CO}_{3}{ }^{2-}=\mathrm{La}\left(\mathrm{CO}_{3}\right)_{2}-$ & 8.33 & $\begin{array}{l}\text { Ohta and Kawabe } \\
(2000)\end{array}$ \\
\hline $\mathrm{Nd}^{3+}+\mathrm{CO}_{3}{ }^{2-}=\mathrm{NdCO}_{3}{ }^{+}$ & 13.59 & $\begin{array}{l}\text { Ohta and Kawabe } \\
(2000)\end{array}$ \\
\hline $\mathrm{Nd}^{3+}+2 \mathrm{CO}_{3}^{2-}=\mathrm{Nd}\left(\mathrm{CO}_{3}\right)_{2}^{-}$ & 8.75 & $\begin{array}{l}\text { Ohta and Kawabe } \\
(2000)\end{array}$ \\
\hline $\mathrm{CO}_{2(\mathrm{~g})}+\mathrm{H}_{2} \mathrm{O}=\mathrm{H}^{+}+\mathrm{HCO}_{3}^{-}$ & -7.8136 & Johnson et al. (2000) \\
\hline $\mathrm{HCO}_{3}{ }^{-}+\mathrm{H}^{+}=\mathrm{CO}_{2(\mathrm{aq})}+\mathrm{H}_{2} \mathrm{O}$ & 6.3447 & Johnson et al. (2000) \\
\hline $\mathrm{HCO}_{3}^{-}=\mathrm{H}^{+}+\mathrm{CO}_{3}^{2-}$ & -10.3288 & Johnson et al. (2000) \\
\hline $\mathrm{H}_{2} \mathrm{O}=\mathrm{H}^{+}+\mathrm{OH}^{-}$ & -13.9951 & Johnson et al. (2000) \\
\hline $\mathrm{NdOHCO}_{3(\mathrm{HB})} \rightarrow \mathrm{REE}^{3+}+\mathrm{OH}^{-}+\mathrm{CO}_{3}{ }^{2-}$ & $-23.8 \pm 0.1$ & This study \\
\hline $\mathrm{LaOHCO}_{3(\mathrm{HB})} \rightarrow \mathrm{REE}^{3+}+\mathrm{OH}^{-}+\mathrm{CO}_{3}^{2-}$ & $-24.1 \pm 0.3$ & This study \\
\hline $\mathrm{NdOHCO}_{3 \text { (Kozoite) }} \rightarrow \mathrm{REE}^{3+}+\mathrm{OH}^{-}+\mathrm{CO}_{3}{ }^{2-}$ & $-22.3 \pm 0.2$ & This study \\
\hline
\end{tabular}

aqueous REE concentrations followed by the stabilization of $\mathrm{pH}$ and REE concentrations (Fig. 5). Analysis of the precipitated solids by XRD showed that kozoite precipitated from aqueous solutions having a $\mathrm{pH}$ below 7, even if hydroxylbastnasite was present in the reactor from the dissolution stage of the experiment. However, it was possible to precipitate hydroxylbastnasite at higher $\mathrm{pH}$, as confirmed by the presence of only hydroxylbastnasite by XRD in the solid materials recovered from these experiments.

\subsection{Stoichiometry of dissolution}

Since both hydroxylbastnasite and kozoite release hydroxyl ions during dissolution, the reactive fluid $\mathrm{pH}$ can be used to assess the stoichiometry of dissolution. This can be illustrated by calculating the $\mathrm{pH}$ of the experiments based on thermodynamic considerations (see Section 2.4 'Thermodynamic modelling' for details) using the measured aqueous REE concentrations and initial reactive aqueous solution composition and assuming stoichiometric dissolution. The comparison of these calculated $\mathrm{pH}$, which assume stoichiometric dissolution, with measured pH is shown in Fig. 6. These results demonstrate that there is no systematic preferential release of REE ions compared to $\mathrm{OH}^{-}$ from the minerals, consistent with stoichiometric dissolution. It can also be seen that the uncertainty of the calculated $\mathrm{pH}$ is higher at lower $\mathrm{pH}$. This is caused by the increasing dependence of the $\mathrm{pH}$ on the mass of $\mathrm{REEOHCO}_{3}$ dissolved (calculated using measured REE concentrations, which are subject to analytical uncertainties) with decreasing $\mathrm{pH}$ because of the lower absolute amount of $\mathrm{OH}^{-}$in the aqueous solution.

\subsection{Solubility product calculations}

Our experimental data of aqueous solutions in equilibrium with hydroxylbastnasite and kozoite (Table 2) allow the calculation of the solubility products $\left(K_{S P}\right)$ of these minerals at $25^{\circ} \mathrm{C}$, defined by

$K_{S P}=a_{\mathrm{REE}^{3+}} \cdot a_{\mathrm{OH}^{-}} \cdot a_{\mathrm{CO}_{3}{ }^{2-}}$

where $a_{i}$ are the activities of the aqueous species $i$, corresponding to the dissolution reaction

$\mathrm{REEOHCO}_{3(\mathrm{~s})} \rightarrow \mathrm{REE}^{3+}+\mathrm{OH}^{-}+\mathrm{CO}_{3}{ }^{2-}$.

Calculation of activities were carried out in PHREEQC (see Section 2.4 'Thermodynamic modelling' for details), and the resulting $K_{S P}$ of the individual experiments are listed in Table 2 . The logarithms of the mean solubility products are $-23.8 \pm 0.1,-24.1 \pm 0.3$, and $-22.3 \pm 0.2$ for Nd-hydroxylbastnasite, La-hydroxylbastnasite, and Nd-kozoite, respectively ( cf. Table 1 ). The values for hydroxylbastnasite are in close agreement with corresponding solubility products calculated from calorimetric data by Rorif et al. (2005), which are $-23.7 \pm 0.6$, $-23.3 \pm 0.6$ for the Nd and La endmembers, respectively. The solubility product of Nd-kozoite, which was previously determined by Carroll (1993) as $-21.7 \pm 0.3$ (converted from the originally published dissolution reaction version using thermodynamic data described in Section 2.4 'Thermodynamic modelling') is also close to that determined from our experiments. Runde et al. (1992) determined a value of $\log \left(K_{S P}\right)=-19.94 \pm 0.16$ for orthorhombic $\mathrm{NdOHCO}_{3}$ in $0.1 \mathrm{M}$ ionic strength aqueous solution, which was converted to zero ionic strength by Rorif et al. (2005), yielding a value of $-21.4 \pm 0.3$. Similarly, Rorif et al. (2005) report $\log \left(K_{S P}\right)$ at zero ionic strength of $-20.7 \pm 0.2$ and $-21.6 \pm 0.4$, calculated from data reported by Meinrath and Kim (1991) and Meinrath and Takeishi (1993), respectively. These three values are slightly higher than that determined in this study. This difference might be caused by the lack of reversal of thermodynamic equilibrium in these past studies, which approached the solubility only from supersaturation. 
Table 2

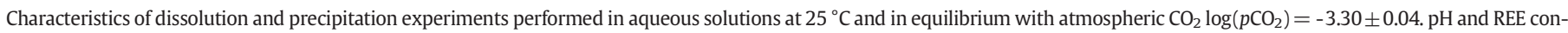

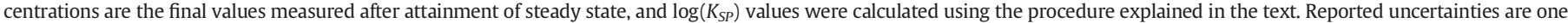

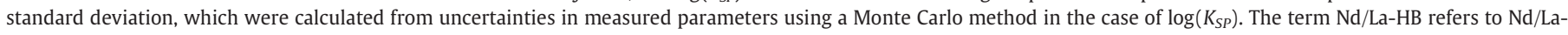

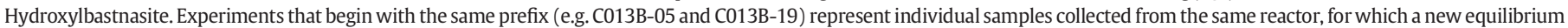
was established by addition of small amounts of $\mathrm{HCl}$ or $\mathrm{NaOH}$ and subsequent dissolution or precipitation of the mineral of interest (see Section 2.2 'Thermodynamic modelling').

\begin{tabular}{|c|c|c|c|c|c|c|c|c|}
\hline Exp. number & Mineral & $\mathrm{pH}$ (final) & $\mathrm{REE} /(\mathrm{mol} / \mathrm{kg})$ & $\mathrm{NaCl} /(\mathrm{mol} / \mathrm{kg})^{\mathrm{a}}$ & $\mathrm{HCl} /(\mathrm{mol} / \mathrm{kg})^{\mathrm{a}}$ & $\mathrm{NaOH} /(\mathrm{mol} / \mathrm{kg})^{\mathrm{a}}$ & $\mathrm{I} /(\mathrm{mol} / \mathrm{L})$ & $\log \left(K_{S P}\right)$ \\
\hline \multicolumn{9}{|c|}{ Dissolution experiments } \\
\hline C012A & Nd-HB & $5.07 \pm 0.04$ & $(3.3 \pm 0.2) \times 10^{-4}$ & 0 & $(1.08 \pm 0.07) \times 10^{-3}$ & 0 & $(2.1 \pm 0.1) \times 10^{-3}$ & $-24.0 \pm 0.2$ \\
\hline C013A-05 & Nd-HB & $6.03 \pm 0.09$ & $(3.8 \pm 0.4) \times 10^{-6}$ & $(9.67 \pm 0.03) \times 10^{-4}$ & 0 & 0 & $(9.87 \pm 0.04) \times 10^{-4}$ & $-23.1 \pm 0.3$ \\
\hline C013B-05 & Nd-HB & $5.91 \pm 0.09$ & $(2.3 \pm 0.1) \times 10^{-6}$ & $(9.70 \pm 0.03) \times 10^{-4}$ & 0 & 0 & $(9.83 \pm 0.03) \times 10^{-4}$ & $-23.6 \pm 0.3$ \\
\hline C013A-11 & Nd-HB & $5.31 \pm 0.09$ & $(3.6 \pm 0.2) \times 10^{-5}$ & $(9.67 \pm 0.03) \times 10^{-4}$ & $\begin{array}{l}(1.005 \pm 0.006) \times \\
10^{-4}\end{array}$ & 0 & $(1.174 \pm 0.005) \times 10^{-3}$ & $-24.2 \pm 0.3$ \\
\hline $\mathrm{C} 015$ & $\mathrm{Nd}-\mathrm{HB}$ & $7.16 \pm 0.09$ & $(6.5 \pm 0.3) \times 10^{-9}$ & $\begin{array}{l}(1.001 \pm 0.004) \times \\
10^{-3}\end{array}$ & 0 & $(9.7 \pm 0.2) \times 10^{-5}$ & $(1.098 \pm 0.004) \times 10^{-3}$ & $-23.86 \pm 0.03$ \\
\hline C029 & Nd-HB & $8.10 \pm 0.04$ & $(1.38 \pm 0.05) \times 10^{-9}$ & $(1.0 \pm 0.2) \times 10^{-3}$ & 0 & $(1.05 \pm 0.01) \times 10^{-3}$ & $(2.1 \pm 0.2) \times 10^{-3}$ & $-23.65 \pm 0.02$ \\
\hline C021-05 & La-HB & $5.78 \pm 0.04$ & $(5.29 \pm 0.06) \times 10^{-6}$ & $(1.00 \pm 0.02) \times 10^{-2}$ & 0 & 0 & $(1.00 \pm 0.02) \times 10^{-2}$ & $-23.8 \pm 0.1$ \\
\hline C021-15 & La-HB & $5.29 \pm 0.04$ & $(3.98 \pm 0.04) \times 10^{-5}$ & $(1.00 \pm 0.02) \times 10^{-2}$ & $(1.02 \pm 0.02) \times 10^{-4}$ & 0 & $(1.02 \pm 0.03) \times 10^{-2}$ & $-24.4 \pm 0.1$ \\
\hline $\mathrm{C} 022$ & Nd-Kozoite & $5.70 \pm 0.04$ & $(3.17 \pm 0.07) \times 10^{-4}$ & $(8.9 \pm 0.2) \times 10^{-3}$ & $\begin{array}{l}(1.01 \pm 0.01) \times \\
10^{-3}\end{array}$ & 0 & $(1.09 \pm 0.02) \times 10^{-2}$ & $-22.3 \pm 0.1$ \\
\hline \multicolumn{9}{|c|}{ Precipitation experiments } \\
\hline C013B-11 & Nd-HB & $7.10 \pm 0.09$ & $(3.5 \pm 0.2) \times 10^{-9}$ & $(9.70 \pm 0.03) \times 10^{-4}$ & 0 & $(10.0 \pm 0.2) \times 10^{-5}$ & $(1.070 \pm 0.003) \times 10^{-3}$ & $-24.12 \pm 0.03$ \\
\hline C013B-19 & Nd-HB & $8.22 \pm 0.09$ & $(6.7 \pm 0.3) \times 10^{-10}$ & $(9.70 \pm 0.03) \times 10^{-4}$ & 0 & $(9.72 \pm 0.06) \times 10^{-4}$ & $(1.945 \pm 0.007) \times 10^{-3}$ & $-23.98 \pm 0.02$ \\
\hline C014 & Nd-Kozoite & $5.65 \pm 0.05$ & $(4.7 \pm 0.5) \times 10^{-4}$ & 0 & $(9.4 \pm 0.2) \times 10^{-3}$ & $\begin{array}{l}(7.691 \pm 0.009) \times \\
10^{-3}\end{array}$ & $(1.08 \pm 0.02) \times 10^{-2}$ & $-22.3 \pm 0.1$ \\
\hline C019 & Nd-Kozoite & $5.68 \pm 0.05$ & $(3.95 \pm 0.03) \times 10^{-4}$ & 0 & $(1.01 \pm 0.02) \times 10^{-2}$ & $(9.0 \pm 0.1) \times 10^{-3}$ & $(1.11 \pm 0.03) \times 10^{-2}$ & $-22.3 \pm 0.2$ \\
\hline
\end{tabular}

a These values refer to the concentration of salts added to create the reactive fluid used in the experiment.

Fig. 7 shows modelled Nd concentrations in equilibrium with the $\mathrm{Nd}$ endmembers of the two minerals as function of $\mathrm{pH}$, calculated using the solubility products determined in this study and assuming a $\log \left(p \mathrm{CO}_{2}\right)$ of -3.30 (as in the experiments). Comparison to the experimental data shows that they are in close agreement with the predicted shape of the solubility curve. It can also be seen that dissolution and precipitation experiments are consistent with each other and with thermodynamic equilibrium.

\section{Discussion}

The experimental data obtained for Nd-hydroxylbastnasite and $\mathrm{Nd}-$ kozoite indicate that the former is more stable at $25^{\circ} \mathrm{C}$ because of its lower solubility product and therefore lower chemical potential. Furthermore, no significant difference was detected between the solubilities of Nd- and La-hydroxylbastnasite. In the following two sections,
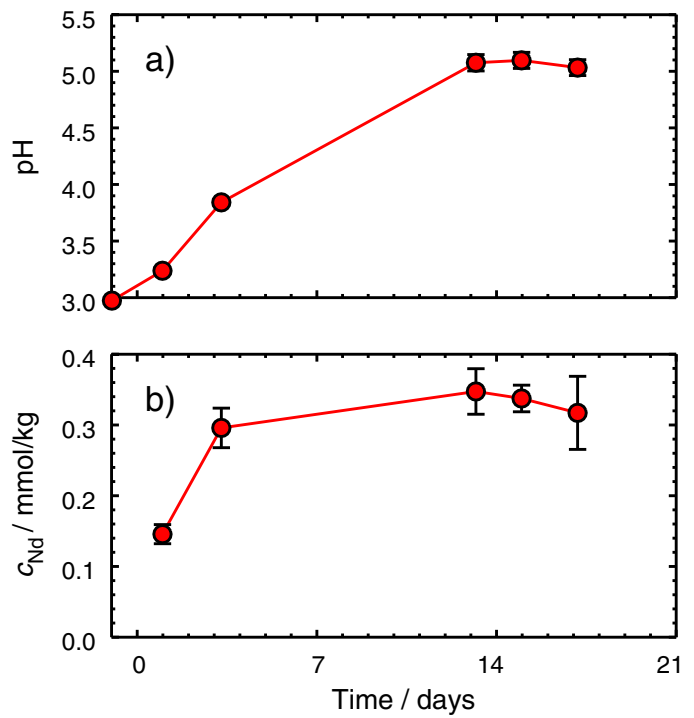

Fig. 4. Evolution of $\mathrm{pH}$ and aqueous $\mathrm{Nd}$ concentrations in dissolution experiment C012A. It can be seen that the dissolution of Nd-hydroxylbastnasite leads to an increase in $\mathrm{Nd}$ and $\mathrm{pH}$ at the beginning of the experiment, before a steady state is achieved at a later stage. Error bars show one standard deviation of the analytical data. we illustrate the stability of hydroxylbastnasite in natural aqueous solutions. For this purpose, we compare the stability of hydroxylbastnasite with fluorobastnasite in presence of variable aqueous fluorine concentrations, and with monazite because of its widespread distribution in the continental crust (Poitrasson et al., 2004).

\subsection{Comparison to fluorobastnasite}

Bastnasite found in nature is usually compositionally closer to the fluorobastnasite endmember $\left(\mathrm{REEFCO}_{3}\right)$ than to hydroxylbastnasite, making a comparison of their relative solubilities especially interesting. However, a direct comparison is not possible at the moment due to the lack of direct solubility measurements of fluorobastnasite in aqueous
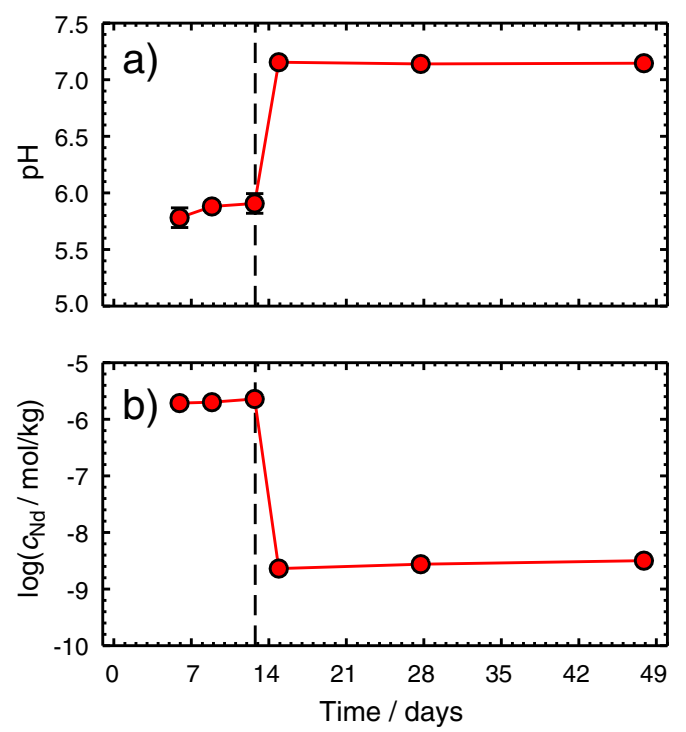

Fig. 5. Evolution of $\mathrm{pH}$ and aqueous $\mathrm{Nd}$ concentrations in precipitation experiment $\mathrm{C} 013 \mathrm{~B}$ Nd-hydroxylbastnasite was added to the reactor in the beginning to achieve a first equilibrium at pH $5.91 \pm 0.09$. After approximately 13 days (dashed line), a small quantity of $\mathrm{NaOH}$ was added to increase the $\mathrm{pH}$ and a new steady state was attained, with a lower Nd concentration due to Nd-hydroxylbastnasite precipitation. Where no error bar is visible, analytical uncertainties (one standard deviation) are within the size of the symbols. 


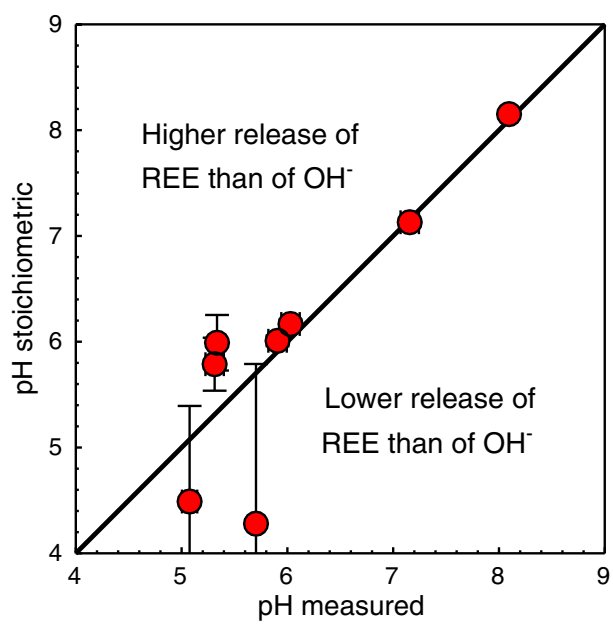

Fig. 6. Measured $\mathrm{pH}$ during the dissolution experiments plotted versus the $\mathrm{pH}$ calculated from measured REE concentrations and the initial solution composition and assuming stoichiometric dissolution. Deviations from the 1:1 line suggest an non-stoichiometric release of REE or $\mathrm{OH}^{-}$from the mineral (see text). Error bars show one standard deviation, calculated with a Monte Carlo type method using analytical uncertainties.

solutions. Nonetheless, an estimate is possible using thermochemical data obtained by Gysi and Williams-Jones (2015), who used results from differential scanning calorimetric experiments on natural bastnasite $\left(\mathrm{Ce}_{0.50} \mathrm{La}_{0.25} \mathrm{Nd}_{0.20} \mathrm{Pr}_{0.05} \mathrm{CO}_{3} \mathrm{~F}\right)$ to calculate a Gibbs free energy of its formation at $25^{\circ} \mathrm{C}$ and $1 \mathrm{bar}$ of $\Delta_{f} G^{\circ}=-1710 \pm 12 \mathrm{~kJ} / \mathrm{mol}$ for this mineral. Using the relationship

$\ln K_{S P}=\frac{-\Delta_{r} G_{d i s s}^{\circ}}{R T}=\frac{-\left(\Delta_{f} G_{R E E_{(a q)}^{3+}}^{\circ}+\Delta_{f} G_{C_{3(a q)}^{2-}}^{\circ}+\Delta_{f} G_{F_{(a q)}^{-}}^{\circ}-\Delta_{f} G_{\text {bastnasite }}^{\circ}\right)}{R T}$

where $R$ refers to the gas constant, and adopting the Gibbs free energies of formation for the aqueous species $\mathrm{Ce}^{3+}, \mathrm{La}^{3+}, \mathrm{Nd}^{3+}, \mathrm{Pr}^{3+}, \mathrm{F}^{-}$and $\mathrm{CO}_{3}{ }^{2-}$ from Oelkers et al. (1995) as well as their estimated uncertainties of up to $600 \mathrm{kcal} / \mathrm{mol}$ in these parameters, a value of $\log \left(K_{S P}\right)=-39 \pm$ 2 is obtained for fluorobastnasite of this composition. Even considering the uncertainties introduced by these calculations, and by the fact that the solubility product for fluorobastnasite was only determined for a mixed-REE mineral, this indicates that bastnasite is stabilized considerably if fluorine is present in the aqueous solution, as demonstrated by the calculated stability fields in Fig. 8, showing that the fluorine endmember is the more stable phase even if only extremely small quantities of aqueous $\mathrm{F}^{-}$are present. For the purpose of this calculation, it was assumed that the difference in solubility of the $\mathrm{NdFCO}_{3}$ endmember compared to the one determined for the mixed-REE mineral by (Gysi et al., 2015) is negligible compared to the uncertainties introduced by the Gibbs free energies of formation for the aqueous species. This result is in agreement with the prevalence of fluorine-rich bastnasite in nature; hydroxylbastnasite, only forms in fluorine-poor systems (Hsu, 1992; Williams-Jones and Wood, 1992).

\subsection{Comparison to monazite}

Monazite $\left(\mathrm{REEPO}_{4}\right)$ is another common rare earth element mineral, which is of interest because of its applications in geosciences (e.g. geochronology and geothermometry) as well as due to its use as an ore mineral (e.g., Poitrasson et al., 2004). The solubility of synthetic $\mathrm{NdPO}_{4}$ has been determined as $\log \left(K_{S P}\right)=-26.02$ (interpolated for $25^{\circ} \mathrm{C}$ ) by Poitrasson et al. (2004), allowing a direct comparison to hydroxylbastnasite. The boundary between the stability fields of the two minerals in equilibrium with aqueous solutions of variable $\mathrm{CO}_{2}$ and phosphorus contents at neutral $\mathrm{pH}$ is shown in Fig. 9, illustrating the potential effect of different $\mathrm{CO}_{2}$ partial pressures in natural systems. It was found that phosphate-REE complexes are only present in negligible quantities under these conditions, as inferred from stability constants of from Haas et al. (1995) and Millero (1992). Although precise data of phosphorus concentrations found in nature are sparse, estimates of lake water P concentrations (Hudson et al., 2000) indicate that monazite is the more stable phase in these waters in equilibrium with atmospheric $\mathrm{CO}_{2}$ levels. Similar to fluorobastnasite, it can be concluded that hydroxylbastnasite is only thermodynamically more stable in phosphorous-poor conditions or at extremely high $\mathrm{CO}_{2}$ partial pressures.

\section{Conclusions}

Dissolution and precipitation experiments of synthetic hydroxylbastnasite and kozoite (hexagonal and orthorhombic $\mathrm{REEOHCO}_{3}$, respectively) were performed in aqueous solutions at $25{ }^{\circ} \mathrm{C}$ to assess

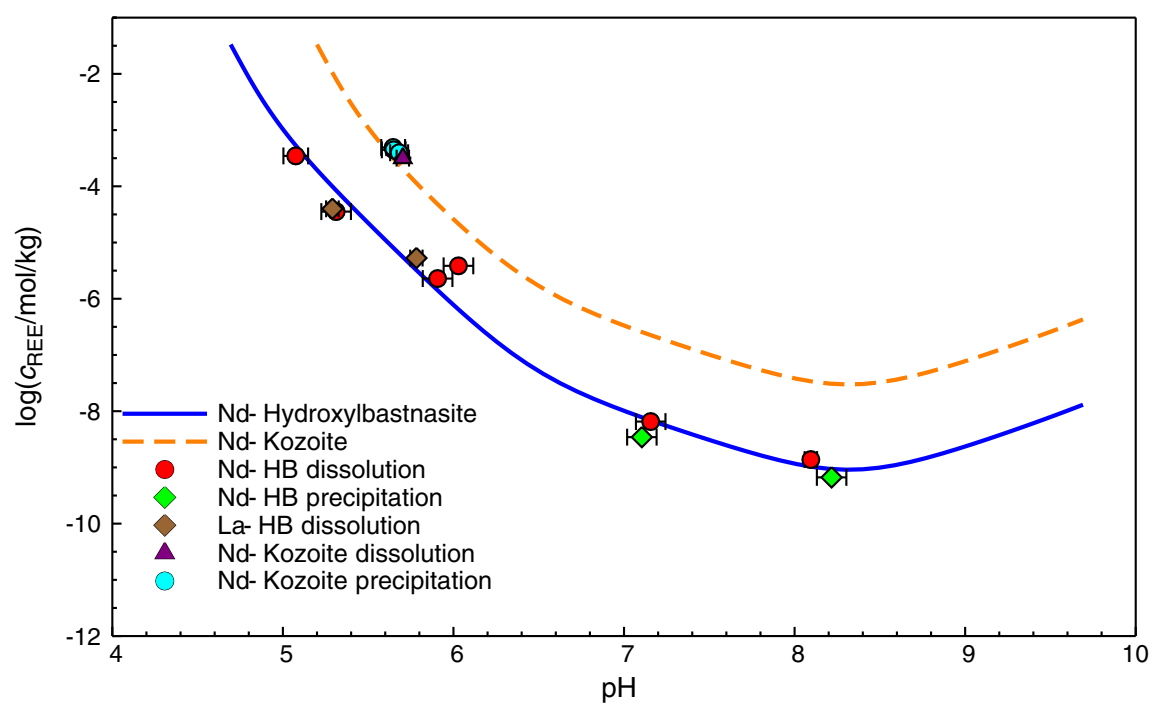

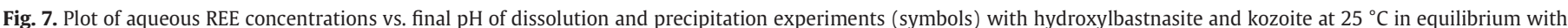

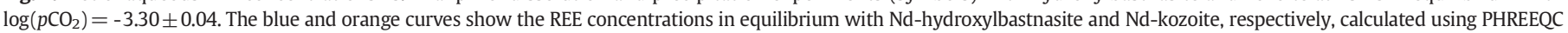

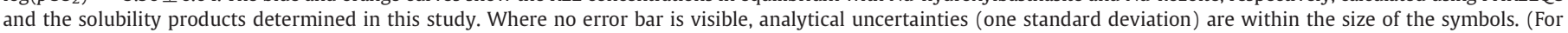
interpretation of the references to color in this figure legend, the reader is referred to the web version of this article.) 


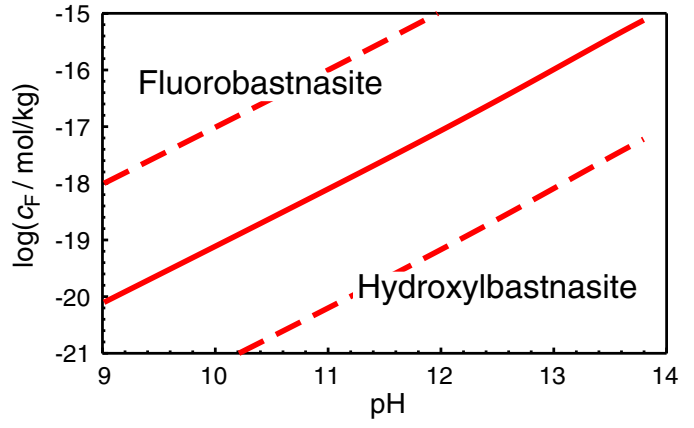

Fig. 8. Plot of the modelled aqueous $\mathrm{F}$ concentration in equilibrium with hydroxylbastnasite and fluorobastnasite (solid line) in aqueous solutions at $25^{\circ} \mathrm{C}$ as a function of $\mathrm{pH}$. The exchange reaction whose equilibrium is illustrated by the solid line can be expressed as $\mathrm{REEOHCO}_{3(\mathrm{~s})}+\mathrm{F}^{-} \leftrightarrow \mathrm{REEFCO}_{3(\mathrm{~s})}+\mathrm{OH}^{-}$. The dashed lines represent the uncerainties (one standard deviation), calculated from the uncertainties in the thermodynamic properties of the minerals. See text for the details of the model calculations.

the solubility of these minerals. For Nd-kozoite, the solubility product was determined to be $\log \left(K_{S P}\right)=-22.3 \pm 0.2$, which is in good agreement with data obtained previously using a similar methodology (Carroll, 1993; Meinrath and Kim, 1991; Meinrath and Takeishi, 1993; Runde et al., 1992). Our experiments showed that hydroxylbastnasite is thermodynamically stable compared to kozoite in aqueous solutions under these conditions, and the solubility product of the $\mathrm{Nd}$ endmember is equal to $\log \left(K_{S P}\right)=-23.8 \pm 0.1$. To our knowledge, this is the first direct determination of hydroxylbastnasite solubility in aqueous solutions, and our $K_{S P}$ is consistent with the value calculated from calorimetric data by Rorif et al. (2005). Furthermore, it was found that the solubility of La-hydroxylbastnasite does not differ significantly from the Nd endmember within the precision achieved in this study.

Comparison of the solubility of hydroxylbastnasite with that of fluorobastnasite (inferred from calorimetric data of Gysi and Williams-Jones (2015)) shows that the fluorine endmember is stable even if only small quantities of fluorine are present in aqueous solution. This explains the prevalence of fluorine-rich bastnasite in natural environments, whereas hydroxylbastnasite only forms in fluorine-devoid systems (Hsu, 1992; Williams-Jones and Wood, 1992). Similarly, it can be seen from comparison to monazite (Poitrasson et al., 2004) hydroxylbastnasite is only stable if phosphorous concentrations are lower than commonly found in nature or if the $\mathrm{CO}_{2}$ partial pressure is extremely high.

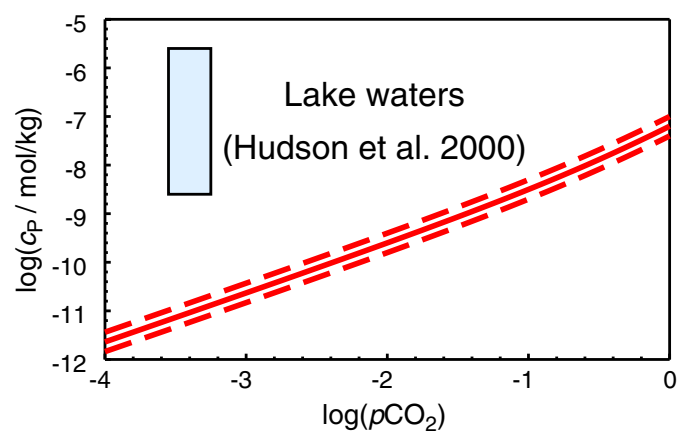

Fig. 9. Plot of the aqueous $\mathrm{P}$ concentrations in equilibrium with Nd-hydroxylbastnasite and Nd-monazite (solid line) in aqueous solutions at $25^{\circ} \mathrm{C}$ and $\mathrm{pH} 7$ as a function of $\mathrm{pCO}_{2}$. The dashed lines represent the uncertainties (one standard deviation), calculated from the uncertainties in the thermodynamic properties of the minerals. See text for the details of the model calculations. The blue rectangle shows the approximate range of phosphorous concentrations in natural lake waters (Hudson et al., 2000) and atmospheric $\mathrm{CO}_{2}$ concentrations. (For interpretation of the references to color in this figure legend, the reader is referred to the web version of this article.)
Although our results expand the dataset of thermodynamic stabilities of rare earth element minerals in aqueous solutions at $25^{\circ} \mathrm{C}$ and provide robust values for their solubility products, there is still a lack of solubility measurements of bastnasite at higher temperatures as well as equivalent data for fluorobastnasite at $25{ }^{\circ} \mathrm{C}$. Difficulties in $K_{S P}$ measurements at high temperature is partly due to the lack of reliable data for the stabilities of the various aqueous complexes that REEs form with carbonate and hydroxyl ions, which are relatively small at $25^{\circ} \mathrm{C}$, but could play a major role at higher temperature (Haas et al., 1995). Furthermore, there is no available data on the dissolution and precipitation kinetics of these REE-carbonate minerals in aqueous solutions. Together with the thermodynamic stabilities determined here, such kinetic data could provide valuable information to assess the conditions of formation and preservation of natural REE mineral deposits, and help to model the fate of actinides that are released from nuclear waste storage sites.

\section{Acknowledgements}

This research was supported by the European Union FP7 Marie Curie Actions Initial Training Network CO2-REACT (317235). The authors would like to thank Frederic Candaudap and Aurélie Lanzanova for assistance with ICP-MS measurements, as well as Thierry Aigouy and Michel Thibaut for help with SEM- and XRD-measurements, respectively.

\section{References}

Binnemans, K., Jones, P.T., Blanpain, B., Van Gerven, T., Yang, Y., Walton, A., Buchert, M., 2013. Recycling of rare earths: a critical review. J. Clean. Prod. 51, 1-22. http://dx. doi.org/10.1016/j.jclepro.2012.12.037.

Carroll, S.A., 1993. Precipitation of Nd-Ca carbonate solid solution at $25{ }^{\circ} \mathrm{C}$. Geochim. Cosmochim. Acta 57, 3383-3393. http://dx.doi.org/10.1016/0016-7037(93)90546-9.

Charlton, S.R., Parkhurst, D.L., 2011. Modules based on the geochemical model PHREEQC for use in scripting and programming languages. Comput. Geosci. 37, 1653-1663. http://dx.doi.org/10.1016/j.cageo.2011.02.005.

Daveler, S.A., Wolery, T.J., 1992. EQPT, a data file preprocessor for the EQ3/6 software package: user's guide and related documentation (version 7.0). Lawrence Livermore Natl. Lab. UCRl-MA-110662. PT II, pp. 1-89.

Elderfield, H., Greaves, M.J., 1982. The rare earth elements in seawater. Nature 296, 214-219. http://dx.doi.org/10.1038/296214a0.

Elderfield, H., Upstill-Goddard, R., Sholkovitz, E.R., 1990. The rare earth elements in rivers, estuaries, and coastal seas and their significance to the composition of ocean waters. Geochim. Cosmochim. Acta 54, 971-991. http://dx.doi.org/10.1016/00167037(90)90432-K.

Gysi, A.P., Williams-Jones, A.E., 2015. The thermodynamic properties of bastnäsite-(Ce) and parisite-(Ce). Chem. Geol. 392, 87-101. http://dx.doi.org/10.1016/j.chemgeo. 2014.11.001.

Gysi, A.P., Williams-Jones, A.E., Harlov, D., 2015. The solubility of xenotime-(Y) and other HREE phosphates $\left(\mathrm{DyPO}_{4}, \mathrm{ErPO}_{4}\right.$ and $\left.\mathrm{YbPO}_{4}\right)$ in aqueous solutions from 100 to $250^{\circ} \mathrm{C}$ and psat. Chem. Geol. 401, 83-95. http://dx.doi.org/10.1016/j.chemgeo.2015.02.023.

Haas, J.R., Shock, E.L., Sassani, D.C., 1995. Rare earth elements in hydrothermal systems: estimates of standard partial molal thermodynamic properties of aqueous complexes of the rare earth elements at high pressures and temperatures. Geochim. Cosmochim. Acta 59, 4329-4350. http://dx.doi.org/10.1016/0016-7037(95)00314-P.

Harlov, D.E., Wirth, R., Hetherington, C.J., 2010. Fluid-mediated partial alteration in monazite: the role of coupled dissolution-reprecipitation in element redistribution and mass transfer. Contrib. Mineral. Petrol. 162, 329-348. http://dx.doi.org/10.1007/ s00410-010-0599-7.

Helgeson, H.C., 1969. Thermodynamics of hydrothermal systems at elevated temperatures and pressures. Am. J. Sci. 267, 729-804. http://dx.doi.org/10.2475/ajs.267.7.729.

Hsu, D.L.C., 1992. Synthesis and stability of bastnaesites in a part of the system (Ce,La)-FH-C-O. Mineral. Petrol. 47, 87-101. http://dx.doi.org/10.1007/BF01165299.

Hudson, J.J., Taylor, W.D., Schindler, D.W., 2000. Phosphate concentrations in lakes. Nature 406, 54-56. http://dx.doi.org/10.1038/35017531.

Johnson, J., Anderson, G., Parkhurst, D., 2000. Database “thermo.com.V8.R6.230.”. Lawrence Livermore Natational Laboratory, Livermore, California, USA.

Jordens, A., Cheng, Y.P., Waters, K.E., 2013. A review of the beneficiation of rare earth element bearing minerals. Miner. Eng. 41, 97-114. http://dx.doi.org/10.1016/j.mineng. 2012.10.017.

Kadis, R., Leito, I., 2010. Evaluation of the residual liquid junction potential contribution to the uncertainty in $\mathrm{pH}$ measurement: a case study on low ionic strength natural waters. Anal. Chim. Acta 664, 129-135. http://dx.doi.org/10.1016/j.aca.2010.02.007.

Lipin, B.R., McKay, G.A., 1989. Geochemistry and mineralogy of rare earth elements. Rev. Mineral. Geochem. 21, 348.

Mckenzie, D., Onions, R., 1991. Partial melt distributions from inversion of rare-earth element concentrations. J. Petrol. 32, 1021-1091. http://dx.doi.org/10.1093/petrology/ 32.5.1021. 
McLellan, B.C., Corder, G.D., Ali, S.H., 2013. Sustainability of rare earths-an overview of the state of knowledge. Minerals 3, 304-317. http://dx.doi.org/10.3390/min3030304.

Meinrath, G., Kim, J.I., 1991. Solubility products of different Am(III) and Nd(III) carbonates. Eur. J. Solid State Inorg. Chem. 28, 383-388.

Meinrath, G., Takeishi, H., 1993. Solid-liquid equilibria of $\mathrm{Nd}^{3+}$ in carbonate solutions. J. Alloys Compd. 194, 93-99. http://dx.doi.org/10.1016/0925-8388(93)90651-3.

Migdisov, A.A., Williams-Jones, A.E., 2014. Hydrothermal transport and deposition of the rare earth elements by fluorine-bearing aqueous liquids. Mineral. Deposita 49 987-997. http://dx.doi.org/10.1007/s00126-014-0554-z.

Migdisov, A.A., Williams-Jones, A.E., Wagner, T., 2009. An experimental study of the solubility and speciation of the rare earth elements (III) in fluoride- and chloride-bearing aqueous solutions at temperatures up to $300{ }^{\circ} \mathrm{C}$. Geochim. Cosmochim. Acta 73 , 7087-7109.

Millero, F.J., 1992. Stability constants for the formation of rare earth-inorganic complexes as a function of ionic strength. Geochim. Cosmochim. Acta 56, 3123-3132. http://dx. doi.org/10.1016/0016-7037(92)90293-R.

Ni, Y., Hughes, J.M., Mariano, A.N., 1993. The atomic arrangement of bastnäsite-(Ce), Ce $\left(\mathrm{CO}_{3}\right) \mathrm{F}$, and structural elements of synchysite-(Ce), röntgenite- $(\mathrm{Ce})$, and parisite(Ce). Am. Mineral. 78, 415-418.

Oelkers, E.H., Helgeson, H.C., Shock, E.L., Sverjensky, D.A., Johnson, J.W., Pokrovskii, V.A. 1995. Summary of the apparent standard partial molal Gibbs free energies of formation of aqueous species, minerals, and gases at pressures 1 to 5000 bars and temperatures 25 to $1000{ }^{\circ} \mathrm{C}$. J. Phys. Chem. Ref. Datas 24, 1401-1560. http://dx.doi.org/10. $1063 / 1.555976$

Ohta, A., Kawabe, I., 2000. Rare earth element partitioning between Fe oxyhydroxide precipitates and aqueous $\mathrm{NaCl}$ solutions doped with $\mathrm{NaHCO}_{3}$ : determinations of rare earth element complexation constants with carbonate ions. Geochem. J. 34, 439-454. http://dx.doi.org/10.2343/geochemj.34.439.

Parkhurst, D.L., Appelo, C.A.J., 2013. Description of input and examples for PHREEOC version 3 - a computer program for speciation, batch-reaction, one-dimensional transport, and inverse geochemical calculations. U.S. Geological Survey Techniques and Methods, Book 6. U.S. Geological Survey, p. 497 (Chapter A43).

Poitrasson, F., Oelkers, E.H., Schott, J., Montel, J.-M., 2004. Experimental determination of synthetic $\mathrm{NdPO}_{4}$ monazite end-member solubility in water from $21{ }^{\circ} \mathrm{C}$ to $300{ }^{\circ} \mathrm{C}$ : implications for rare earth element mobility in crustal fluids. Geochim. Cosmochim. Acta 68, 2207-2221. http://dx.doi.org/10.1016/j.gca.2003.12.010.

Preinfalk, C., Morteani, G., 1989. The industrial applications of rare earth elements. In: Möller, P.D.P., Černý, P.D.P., Saupé, P.D.F. (Eds.), Lanthanides, Tantalum and
NiobiumSpecial Publication No. 7 of the Society for Geology Applied to Mineral Deposits. Springer Berlin Heidelberg, pp. 359-370.

Rorif, F., Fuger, J., Desreux, J.F., 2005. Thermochemistry of selected trivalent lanthanide and americium compounds: orthorhombic and hexagonal hydroxycarbonates. Radiochim. Acta Int. J. Chem. Asp. Nucl. Sci. Technol. 93, 103-110. http://dx.doi.org/ 10.1524/ract.93.2.103.59419.

Runde, W., Meinrath, G., Kim, J.I., 1992. A study of solid-liquid phase equilibria of trivalent lanthanide and actinide ions in carbonate systems. Radiochim. Acta 58-59, 93-100. http://dx.doi.org/10.1524/ract.1992.5859.1.93.

Schnetzler, C.C., Philpotts, J.A., 1970. Partition coefficients of rare-earth elements between igneous matrix material and rock-forming mineral phenocrysts-II. Geochim. Cosmochim. Acta 34, 331-340. http://dx.doi.org/10.1016/0016-7037(70)90110-9.

Smith, M.P., Campbell, L.S., Kynicky, J., 2015. A review of the genesis of the world class Bayan Obo Fe-REE-Nb deposits, Inner Mongolia, China: multistage processes and outstanding questions. Ore Geol. Rev. 64, 459-476. http://dx.doi.org/10.1016/j. oregeorev.2014.03.007.

Stipp, S.L.S., Christensen, J.T., Lakshtanov, L.Z., Baker, J.A., Waight, T.E., 2006. Rare earth element (REE) incorporation in natural calcite: upper limits for actinide uptake in a secondary phase. Radiochim. Acta 94, 523-528. http://dx.doi.org/10.1524/ract.2006. 94.9-11.523.

Tahara, T., Nakai, I., Miyawaki, R., Matsubara, S., 2007. Crystal chemistry of RE $\left(\mathrm{CO}_{3}\right) \mathrm{OH}$. Z. Krist. 222, 326-334. http://dx.doi.org/10.1524/zkri.2007.222.7.326.

Taylor, S., Mclennan, S., 1995. The geochemical evolution of the continental-crust. Rev. Geophys. 33, 241-265. http://dx.doi.org/10.1029/95RG00262.

Vallina, B., Rodriguez-Blanco, J.D., Blanco, J.A., Benning, L.G., 2014. The effect of heating rates on the morphology of crystalline neodymium carbonates. Mineral. Mag. 78, 1391-1397. http://dx.doi.org/10.1180/minmag.2014.078.6.05.

Vallina, B., Rodriguez-Blanco, J.D., Brown, A.P., Blanco, J.A., Benning, L.G., 2015. The role of amorphous precursors in the crystallization of La and Nd carbonates. Nanoscale 7, 12166-12179. http://dx.doi.org/10.1039/C5NR01497B.

Wang, X., Lei, Y., Ge, J., Wu, S., 2015. Production forecast of China's rare earths based on the generalized Weng model and policy recommendations. Resour. Policy 43, 11-18. http://dx.doi.org/10.1016/j.resourpol.2014.11.002.

Williams-Jones, A.E., Wood, S.A., 1992. A preliminary petrogenetic grid for REE fluorocarbonates and associated minerals. Geochim. Cosmochim. Acta 56, 725-738. http://dx.doi.org/10.1016/0016-7037(92)90093-X.

Wübbeke, J., 2013. Rare earth elements in China: policies and narratives of reinventing an industry. Resour. Policy 38, 384-394. http://dx.doi.org/10.1016/j.resourpol.2013.05.005. 